\title{
The effect of used engine oil on carbohydrate, mineral content and nitrate reductase activity of leafy vegetable (Amaranthus hybridus L.)
}

\author{
*ODJEGBA, V J; ATEBE, J O \\ Department of Botany and Microbiology, University of Lagos, Akoka, Yaba, \\ Lagos, Nigeria.
}

\begin{abstract}
The effects of used engine oil on carbohydrate, mineral elements and nitrate reductase activity of Amaranthus hybridus were investigated. Seedlings were grown for 8 weeks in soil containing $0-5 \% \mathrm{v} / \mathrm{w}$ used engine oil. There was a significant $(\mathrm{p}=0.05)$ low level of mineral elements in plants grown in oil treated soils. The carbohydrate content of the control plants was significantly higher than the values observed for plants grown in oil treated soils. The control plants had a mean value of $48.3 \pm 0.5 \mu \mathrm{g} \mathrm{g}^{-1}$ dry wt, while $42.0 \pm 1.0$ and $30.9 \pm 0.4 \mu \mathrm{g} \mathrm{g}$ ${ }^{1}$ dry wt were observed for plants treated with 1 and $5 \%$ oil. There was significant inhibitory effect on nitrate reductase activity in plants that were exposed to engine oil. Therefore, the potential risk of used engine oil as potent environmental pollutant has been established from the results of this study. @JASEM
\end{abstract}

The environmental impacts associated with operations and marketing of petroleum products in Nigeria have become significant in recent times. This might be due to the increasing awareness among the people, the dangers of continued environmental degradation caused by spills of crude oil and its refined products. Pollution from spent engine oil is one of the environmental problems in Nigeria and is more widespread than crude oil pollution (Odjegba and Sadiq 2002). The effects of discharged engine oil on the environment are poorly understood as only limited data exist and these are not readily available.

Spills occur at all stages of production, transportation and handling of the product. This could be as a result of pipeline rupture, accidents and dumping of waste engine oil (Oyibo and Agboola 1983). The local consumption of engine oil in Nigeria is increasing at a very high rate in recent times due to the upsurge in the number of vehicles and other machines that makes use of this lubricant. This directly affects the rate at which the spent lubricant enters and pollutes the environment. Disposal of the spent lubricant into gutters, water drains and vacant plots is a common practice among automobile mechanics that change oil from motor vehicles and power generating machines. The existing mode of indiscriminate disposal of this waste oil increases pollution incidents in the environment. Odjegba and Idowu (2002) reported that germination of Amaranthus hybridus seeds was significantly affected in spent engine oil-polluted soil. While seedlings growth, chlorophyll and protein contents were seriously affected (Odjegba and Sadiq 2002).

Plant nutrition is based not only on the presence of mineral elements but their availability (Clarkson and Hanson 1980). The availability of essential mineral element is influenced by decay of humus, cation exchange capacity of the soil, $\mathrm{pH}$, chelators and micro organisms among others (Robb and Pierpoint 1983). Therefore, pollutants that can alter these factors will affect the availability of the mineral nutrients to the plants. Carbon iv oxide is used up during photosynthesis for the production of carbohydrate which is necessary for the build up of plants' biomass (Marschner 1995).

Nitrate serves as an important source of inorganic nitrogen for plants. It also evokes rapid changes in metabolism that include the induction of the synthesis of nitrate assimilatory enzymes and shifting from starch biosynthesis to the production of organic acids to assimilate ammonium (Foyer et al. 2003). Nitrate absorbed by plants must be reduced to ammonium before incorporation into amino acids (Fan et al. 2002). The first step on the nitrate reductase process is catalysed by the enzyme nitrate reductase (NR). It is an essential plant enzyme in nitrogen assimilation and was the first recognized example of substrateinducible enzyme in plants (Lexa et al. 2002). Activity of this enzyme is considered to be a limiting factor for growth and protein production in plants (Solomonson and Barber 1990). Nitrate reductase activity (NRA) measurements have been used to indicate the effect of changes in the environment on a plant's capacity to assimilate nitrate nitrogen (Fredeen et al. 1991). It has been reported that the activity of this enzyme is inhibited by metals such as copper (Luna et al. 1997); drought (Mahan et al. 1998); and salinity (Ghoulam et al. 2002). To the knowledge of the authors, no work has been done to investigate the influence of spent engine oil on the nitrogen metabolism of leafy vegetables. The study reported here aimed at investigating the effects of this lubricant on carbohydrate, mineral elements and nitrate reductase activity of $A$. hybridus, a leafy 
vegetable widely cultivated in domestic gardens both in rural and urban areas in Nigeria.

\section{MATERIALS AND METHODS}

Sample collection: Seeds of $A$. hybridus used for this study were purchased from a local market in Lagos, Nigeria in a single batch and enough for the study. Spent engine oil was obtained from four different auto-mechanic workshops in Lagos, and the pool was used for the study.

Seedlings were raised from seeds planted on sandyloam $(\mathrm{pH} 7.1)$ nursery bed $(1 \times 5 \mathrm{~m})$ at the Botanic garden of the University of Lagos. Water was added to the nursery bed when necessary to keep it moist. Seedlings attained height range of $7-12 \mathrm{~cm}$ after 2 weeks of planting and were considered matured enough to be transplanted and subjected to treatments.

Sample treatments: For the purpose of this experiment, seedlings of equal height were selected and transplanted into polythene bags $(10.0 \mathrm{~cm}$ wide and $15.0 \mathrm{~cm}$ deep) containing sandy-loam soil treated with spent engine oil to achieve 1, 2, 3, 4 and 5 percent $\mathrm{v} / \mathrm{w}$ oil/soil. Soil treatment with spent engine oil was done as earlier described by Odjegba and Sadiq (2002). Soil devoid of oil served as control. Two seedlings were planted in a polythene bag representing each treatment and this was replicated three times. Each individual seedling was an observation. Five grams of soil, each representing each treatment was collected from the polythene bags for physicochemical analysis. Electrical conductivity (EC) and $\mathrm{pH}$ of aqueous extract were determined immediately after shaking the fresh soil samples in distilled water at $25{ }^{\circ} \mathrm{C}$ for 30 minutes. Seedlings were allowed to grow for a period of 8 weeks and water was added to all samples when necessary in order to keep the soil moist.

Sample analysis: At harvest, plants were carefully removed, washed in running tap water to remove attached soil particles and rinsed with distilled water. Fresh leaves were collected from all the samples for the preparation of leaf extracts used for the enzyme assay. Crude extract was prepared by grinding $0.5 \mathrm{~g}$ of leaves in $10 \mathrm{ml}$ distilled water and the filtrate utilized for enzyme analysis (De Biasi et al. 2003). Enzyme assay was performed within 1hour after plant harvest to avoid loss of enzyme activity. Plants meant for drying were placed in marked paper bags and oven-dried at $70^{\circ} \mathrm{C}$ for 36 hours. Five grams of soil representing each treatment was collected from corresponding polythene bags immediately after harvest for physicochemical analysis as described earlier in this text. Elemental contents in the shoot of dried plant samples $(\mathrm{Ca}, \mathrm{Fe}, \mathrm{K}, \mathrm{Mg}, \mathrm{Na}, \mathrm{N}$ and $\mathrm{P}$ ) were determined. Metal contents were measured using Atomic Absorption Spectrometry (AAS) after acid digestion using conc. $\mathrm{HNO}_{3}$ and $20 \% \mathrm{HCl}$ (Ye et al. 1997). Carbohydrate level in the shoot of the dried plant samples was determined using anthrone- $\mathrm{H}_{2} \mathrm{SO}_{4}$ reagent as described by Hansen and Moller (1975). The glucose content was multiple by 0.9 to obtain the amount of starch (Nakano et al. 2000). The extraction and assay of nitrate reductase was estimated by a modified method of Fan et al. (2002). One milliliter of the crude extract was incubated at room temperature $\left(26{ }^{\circ} \mathrm{C}\right)$ in the dark for 1 hour in 3 $\mathrm{mL}$ of the substrate assay solution in a test tube. The substrate assay solution contained $1 \mathrm{~mL}$ each of $0.1 \mathrm{M}$ $\mathrm{KNO}_{3}, 15 \mathrm{~mL} \mathrm{~L}^{-1}$ propanol and $0.1 M$ potassium phosphate buffer $(\mathrm{pH} 7.5)$. One milliliter of the solution was transferred using a pipette after the incubation period into a clean test tube. One milliliter each of $1 \%$ sulphanilic acid (warm at $40{ }^{\circ} \mathrm{C}$ for $5 \mathrm{~min}$ to dissolve) and $0.02 \%$ naphthylenediamine (NED) was added, the mixture was thoroughly shaken and left to stand for 1 hour to allow full colour development. A blank was prepared by mixing $1 \mathrm{~mL}$ of substrate assay solution, $1 \mathrm{ml}$ of $1 \%$ sulphanilic acid and $1 \mathrm{~mL}$ of $0.02 \%$ naphthylenediamine in a test tube. The mixture was allowed to stand for 1 hour for colour development. Colour development due to nitrite was measured spectrophotometrically at $540 \mathrm{~nm}$. The values were compared to a standard curve generated using solutions of $\mathrm{NaNO}_{2}$.

Statistical analysis: Data were analysed using one way analysis of variance (ANOVA) with differences determined using Duncan's multiple comparisons test. Differences were considered to be significant at a probability of $5 \%(\mathrm{p}=0.05)$.

\section{RESULTS AND DISCUSSION}

In this study, A. hybridus was grown for 8 weeks in soil containing $0-5 \% \mathrm{v} / \mathrm{w}$ used engine oil. The $\mathrm{pH}$ of the soil immediately after oil treatment (initial $\mathrm{pH}$ ) and at the end of the growth period (final $\mathrm{pH}$ ) is as shown in Figure 1. Soil pH demonstrated an increase when amended with used engine oil. The control soil had a $\mathrm{pH}$ value of 7.1 while oil treated soil had $\mathrm{pH}$ values ranging from 7.1-7.5. The $\mathrm{pH}$ values observed after 8 weeks showed a decreasing trend in oil treated soils according to the concentration of oil treatment. The control soil however had a relatively stable $\mathrm{pH}$ as it slightly increased from 7.1-7.2. The significant $(\mathrm{p}=0.05)$ decrease in the final $\mathrm{pH}$ of oil treated soil could be related to oil degradation process by soil microorganisms, making carbon available for chemical reactions in the presence of water that could lead to a reduction in $\mathrm{pH}$.

\section{ODJEGBA, V J; ATEBE, J O}




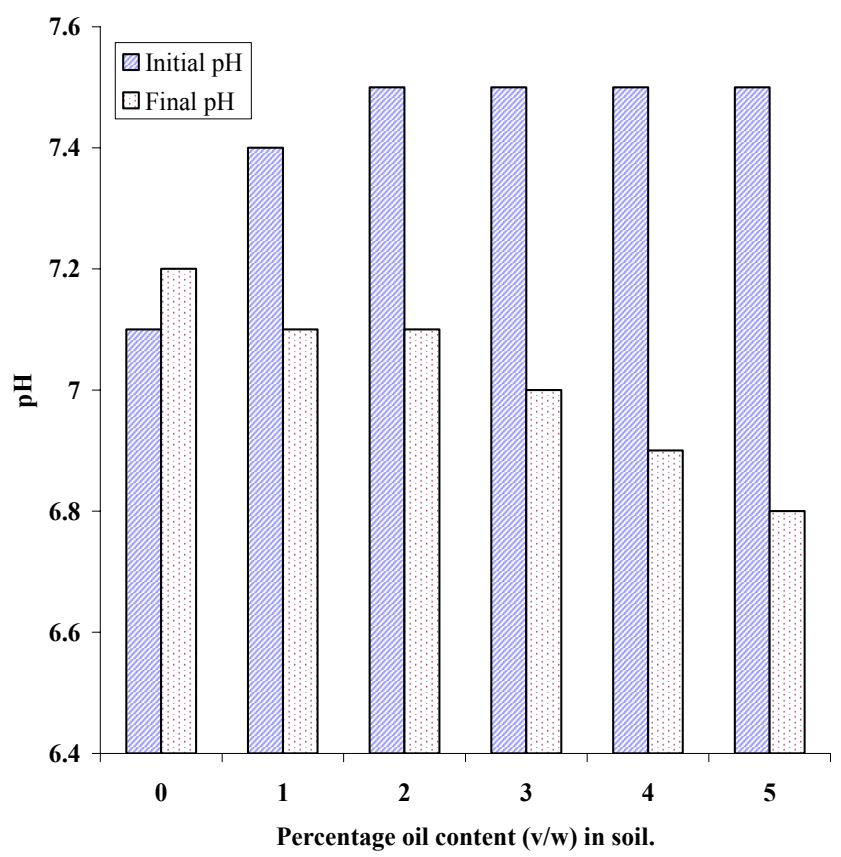

Figure 1: $\mathrm{pH}$ of soil amended with different concentrations of used engine oil at the begining and the end of the experiment period.

Figure 2 shows the electrical conductivity (EC) of the soil with or without used engine oil. There was no significant $(p=0.05)$ difference in the initial EC between the control and the oil treated soil. The EC of the control soil decreased significantly $(p=0.05)$ from 21.3 to $16.9 \mu \mathrm{S} \mathrm{cm}^{-1}$ after 8 weeks. Except for the $1 \%$ oil treated soil, there was no significant decrease in the final EC values of the oil treated soil. Electrical conductivity estimates the amount of total dissolved salts or ions. The significant $(\mathrm{p}=0.05)$ decrease in EC observed for the control and $1 \%$ oil treated soil was due to absorption of mineral nutrients by the plant. However, soil with higher concentrations $(\geq 2 \%)$ had no significant decrease in EC due to the hydrophobic nature of oil that limits the availability of the nutrient elements for plant absorption.

Table 1: Percentage reduction in elemental contents of oil treated plants in relation to the control. Values followed by different letters in the same column differ significantly $(\mathrm{p}=0.05)$ according to Duncan's multiple comparison.

\begin{tabular}{lllllllr}
\hline \% Oil & \multicolumn{6}{l}{ Elements } & \multicolumn{7}{l}{} \\
\cline { 2 - 8 } & $\mathrm{Fe}$ & $\mathrm{Mg}$ & $\mathrm{K}$ & $\mathrm{Na}$ & $\mathrm{Ca}$ & $\mathrm{P}$ & $\mathrm{N}$ \\
1 & $75.93 \mathrm{a}$ & $88.98 \mathrm{a}$ & $76.00 \mathrm{a}$ & $38.46 \mathrm{a}$ & $48.75 \mathrm{a}$ & $33.78 \mathrm{a}$ & $3.39 \mathrm{a}$ \\
2 & $79.63 \mathrm{~b}$ & $91.52 \mathrm{~b}$ & $81.50 \mathrm{~b}$ & $83.67 \mathrm{~b}$ & $61.25 \mathrm{~b}$ & $41.22 \mathrm{~b}$ & $29.94 \mathrm{~b}$ \\
3 & $83.33 \mathrm{c}$ & $92.37 \mathrm{~b}$ & $83.25 \mathrm{~b}$ & $86.11 \mathrm{c}$ & $73.75 \mathrm{c}$ & $50.00 \mathrm{c}$ & $43.52 \mathrm{c}$ \\
4 & $87.70 \mathrm{~d}$ & $96.61 \mathrm{c}$ & $87.50 \mathrm{c}$ & $86.72 \mathrm{c}$ & $81.25 \mathrm{~d}$ & $57.43 \mathrm{~d}$ & $61.11 \mathrm{~d}$ \\
5 & $92.59 \mathrm{e}$ & $97.45 \mathrm{c}$ & $92.50 \mathrm{~d}$ & $91.67 \mathrm{~d}$ & $87.50 \mathrm{e}$ & $60.81 \mathrm{~d}$ & $62.65 \mathrm{~d}$ \\
\hline
\end{tabular}

The mineral elements in the plants expressed as the percentage difference between the levels observed in control and the oil treated plants, is as shown in Table 1. The result shows an increasing trend in the percentage reduction of mineral elements with increasing oil concentration. The mineral elements in the oil treated soil were readily available for plant uptake. This confirmed that plant nutrition is based not only on the presence of minerals elements, but their availability (Clarkson and Hanson 1980). 


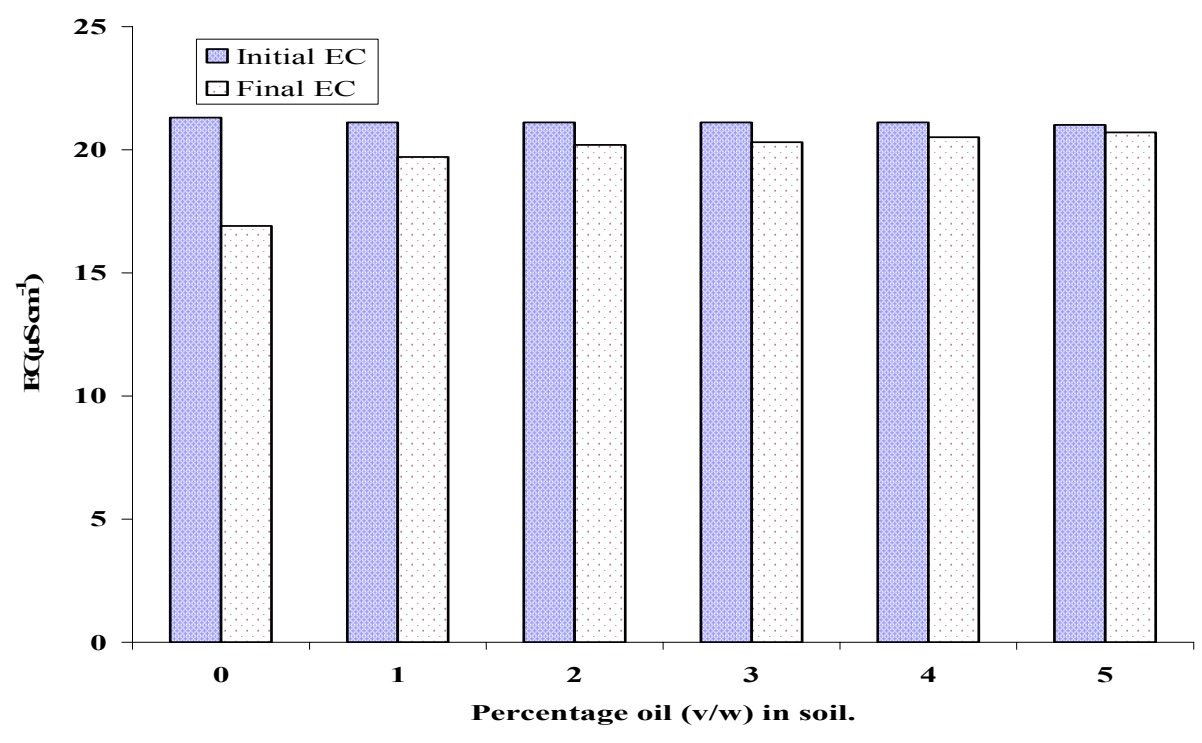

Figure 2: Electrical conductivity (EC) of soil amended with various concentrations of used engine oil at the begining and the end of the experiment period.

Figure 3 shows the effect of used engine oil on the carbohydrate content of $A$. hybridus. The carbohydrate content of the control was significantly $(p=0.05)$ higher than values observed for plants grown in oil treated soil. The control had a mean value of $48.3 \pm 0.5 \mu \mathrm{g} \mathrm{g}^{-1}$ dry wt, compared to $42.0 \pm$ 1.0 and $30.9 \pm 0.4 \mu \mathrm{g} \mathrm{g}^{-1}$ dry wt observed for plants treated with 1 and $5 \%$ oil (Figure 3). The significant reduction in the carbohydrate content of the oil treated plants could be attributed to photosynthetic impairment. It has been reported that plants exposed to sub-lethal doses of used engine oil had low chlorophyll content (Udo and Fayemi 1975; Odjegba and Sadiq 2002), and this could have a direct effect on carbon fixing efficiency of the plant.

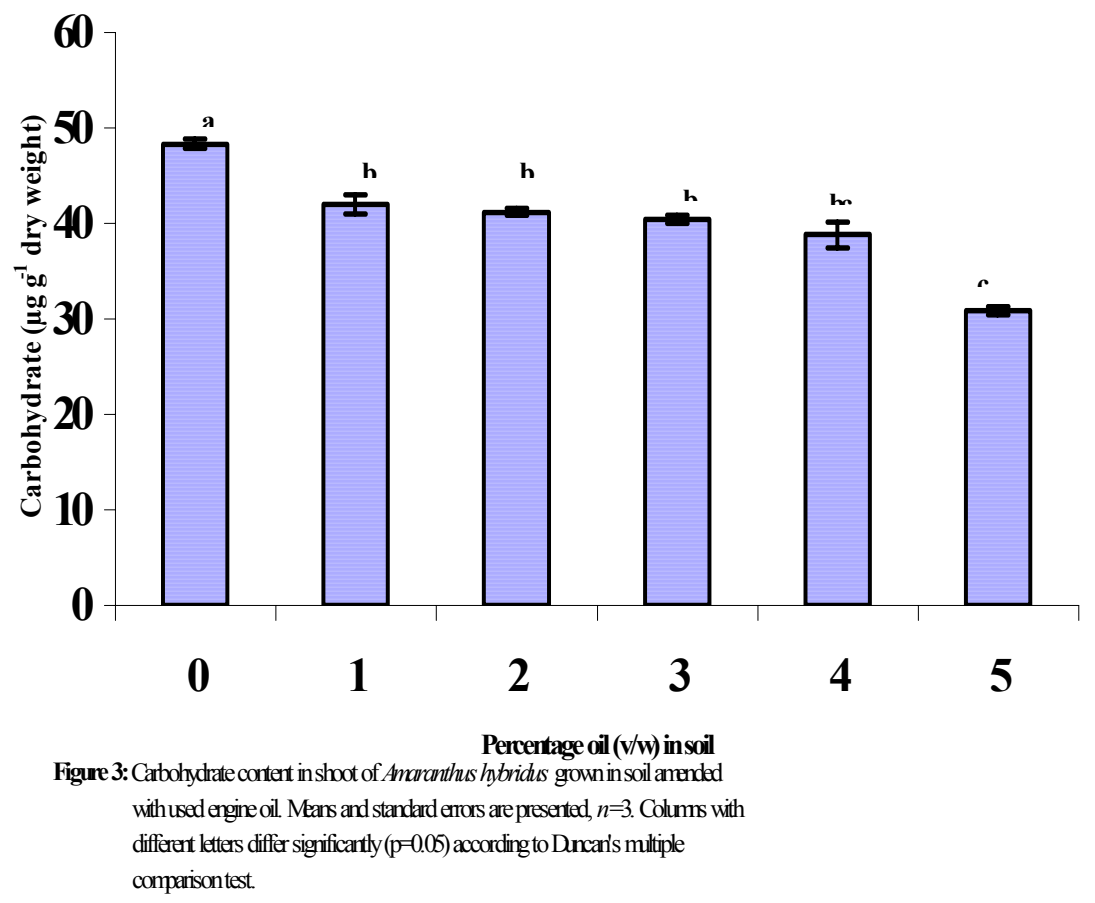

ODJEGBA, V J; ATEBE, J O 
Data showing the effect of used engine oil on the nitrogen metabolism of $A$. hybridus are presented in Figure 4. Significant $(p=0.05)$ inhibitory effect on nitrate reductase activity was observed in oil treated plants. The severity of the effect was proportional to oil concentrations. The inhibitory effect of the used oil could partly be attributed to the toxic nature of some of its constituents on this enzyme. It has been reported that polycyclic aromatic hydrocarbons $(\mathrm{PAH})$ is a toxic and recalcitrant portion of used engine oil (Wang et al. 2000).

The authors conclude that the status of used engine oil as a potent environmental pollutant could be established based on the results presented in this study; therefore, there is need to control the treatment and disposal of used engine oil.

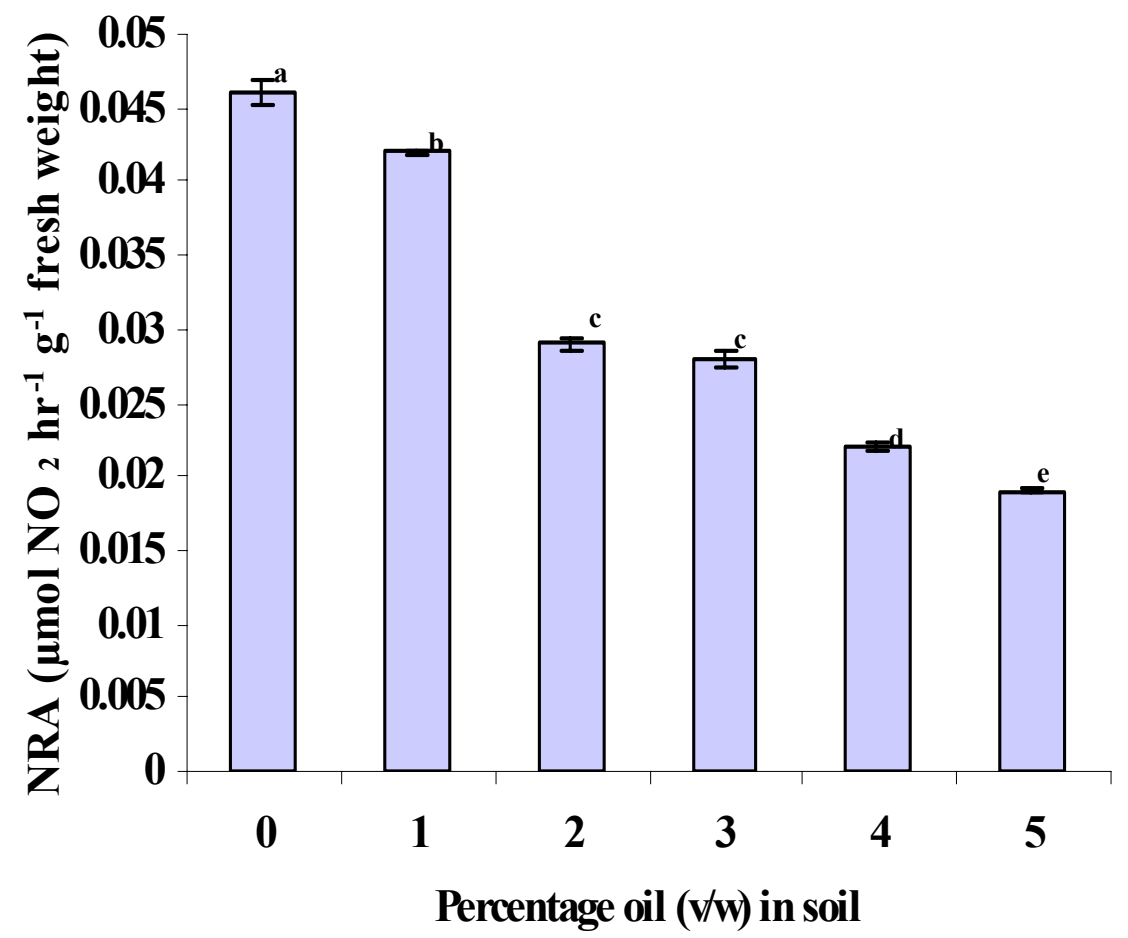

Figure 4: Nitratereductase activityinAmaranthushybridus growninsoilamended

withusedengine oil. Meansandstandarderrorsare presented, $n=3$.

Columns with different letters differ significantly $(\mathrm{p}-0.05)$ accordingto

Duncan'smultiple comparisontest.

\section{REFERENCES}

Clarkson, DT; Hanson, JB (1980). The mineral nutrition of higher plants. Ann Rev Plant Physiol 31: 239-298.

De Biasi, MG; Astolfi, S; Acampora, A; Zuchi, S; Fonzo, V; Satangelo, E; Caccia, R; Badiani, M; Soressi, GP (2003). A $\mathrm{H}_{2} \mathrm{O}_{2}$-forming peroxidase rather than a $\mathrm{NAD}(\mathrm{P}) \mathrm{H}$-dependent $\mathrm{O}_{2}{ }^{-}$synthase may be the major player in cell death responses controlled by the pto-Fen complex following fenthion treatment. Functional Plant Biol 30:409417.

Fan, XH; Tang, C; Rengel, Z (2002). Nitrate uptake, nitrate reductase distribution and their relation to proton release in five nodulated grain legumes. Annals Bot 90:315-323.

Foyer, CH; Parry, M; Noctor, G (2003). Makers and signals associated with nitrogen assimilation in higher plants. J Exp Bot 54: 585-593.

Fredeen, AL; Griffin, K; Field, CB (1991). Effects of light quantity and quality and soil nitrogen status on NRA in rainforest species of the genus Piper. Oecologia 86:441-446.

Ghoulam, C; Foursy, A; Fares, K (2002). Effects of salt stress on growth, inorganic ions and proline accumulation in relation to osmotic adjustment 
in five sugar beet cultivars. Environ Exp Bot 47:39-50.

Hansen, J; Moller, I (1975). Percolation of starch and soluble carbohydrates from plant tissue for quantitative determination with anthrone. Anal Biochem 68:87-94.

Lexa, M; Genkov, T; Brzobohaty, B (2002). Inhibitory effects of elevated endogenous cytokinins on nitrate reductase in ipt-expressing tobacco are eliminated by short-term exposure to benzyladenine. Physiol Plantarum 115:284-290.

Luna, ML; Casano, LM; Trippi; VS (1997). Nitrate reductase is inhibited in leaves of Triticum aestivum treated with high levels of copper. Physiol Plantarum 101: 103-108.

Marschner, H (1995). Mineral nutrition of higher plants. $2^{\text {nd }}$ edition, Academic Press, London. $327 \mathrm{pp}$.

Mahan, JR; Oliver, MJ; Sherman, TD (1998). Nitrate reductase activity during desiccation and rehydration of the desiccation-tolerant moss Tortula ruralis Environ Exp Bot 39: 67-76.

Nakano, H; Muramatsu, S; Makino A; Mae, T (2000). Relationship between the suppression of photosynthesis and starch accumulation in the pod-removed bean. Australian J Plant Physiol 27:167-173.

Odjegba, VJ; Idowu, FS (2002). Effects of spent engine oil on the germination and growth of
Amaranthus hybridus. Biosci Res Comm 14:101105.

Odjegba, VJ; Sadiq, AO (2002). Effects of spent engine oil on the growth parameters, chlorophyll and protein levels of Amaranthus hybridus L. The Environmentalist 22: 23-28.

Oyibo, CO; Agboola, EA (1983). Pollution control in petroleum products marketing operations in Nigeria, pp. 65-70. Petroleum Inspectorate, Warri: Nigerian National Petroleum Corporation.

Robb, DA and Pierpoint, WS (1983). Metals and micronutrients: Uptake and utilization by plants. Academic Press, New York. 234pp.

Solomonson, LP; Barber, MJ (1990). Assimilatory nitrate reductase: functional properties and regulation. Ann Rev Plant Physiol 41:225-253.

Udo, EJ; Fayemi, AA (1975). The effect of oil pollution of soil on germination, growth and nutrient uptake of corn. J Environ Qual 4: 537540.

Wang, J; Jia, CR; Wong, CK; Wong, PK (2000). Characterization of polycyclic aromatic hydrocarbons created in lubricating oils. Water, Air, and Soil Poll 120:

381-396.

Ye, ZH; Baker, AJM; Wong, MH; Willis, AJ (1997). Copper and nickel uptake, accumulation and tolerance in Typha latifolia with and without iron plaque on the root surface. New Phytol 136:481488. 